\title{
Effects of Service Quality on Customer Satisfaction in Nepalese Commercial Banks
}

\author{
- Achyut Gnawali
}

\begin{abstract}
Service Quality and customer satisfaction have long been recognized as playing a crucial role for success and survival in today's competitive market. This study has tried to discover the impact of service quality on customer satisfaction in Nepalese commercial bank. A structured questionnaire with 5 point Likert scale has been used to collect the data by conducting survey. The sample size is 392 and is chosen on a convenient basis. Data has been analyzed by using SPSS software (version: 22).Both primary and secondary sources of data are collected and used. Result of the study shows that tangibility, reliability, responsiveness, assurance and empathy significantly and positively influence customer attitudes in terms of satisfaction, i.e. service quality dimensions are crucial for customer satisfaction in public, private and joint venture commercial banking sector in Nepal.
\end{abstract}

Keywords: service quality, customer satisfaction, regression analysis and financial performance.

\section{Introduction}

Service quality is considered an important tool for a firm's struggle to differentiate itself from its competitors (Ladhari, 2008). Service quality has received a great deal of attention from both academicians and practitioners (Negi, 2009) and service marketing literature defined service quality as the overall assessment of a service by the customer (Eshghiet al., 2007).

Banks have to redefine their corporate image that emphasizes service quality since it provides many advantages to a company such as allowing the company to differentiate itself from its competitors by increasing sales and market shares, providing opportunities for cross selling, improving customer relations thus enhancing the corporate image, reliability, responsiveness, credibility and communication results in the satisfaction and retention of customers and employee, thus reducing turnover rate (Newman, 2001).

Customer satisfaction is one of the important tools to run a business and to achieve the mission statement. Indeed, customer satisfaction has great significance for the future of an institution and it is seen as a basis for securing market position and achieving other objectives of the institution. Therefore, achieving high levels of service is one method to keep customers both satisfied and loyal (Perng, 2007).

1 Gnawali is an Associate Professor of Management, Central Department of Management, T.U.,Kirtipur 
In Nepal, customers in the banking sector are in a strong bargaining position due to the significant growth of banks. There are 31 commercial banks, 78 development banks and 88 finance company operating in Nepal with wide menu of services(NRB,2013). Therefore, banks have to provide service carefully because of the availability of banks. Service quality has been a vital issue of discussion and research over the past three decades. Research on service quality has well established that the customer perception of the quality of a service depends on customer's preservice expectations. Studies by Parasuraman et al. (1985), Zeithmalet al. (1990), noted that the key strategy for the success and survival of any business institution is the deliverance of quality services to customers. Accordingly, Chang (2008) deemed that excellent service quality is vital to business success and survival. Hence, delivering quality service to clients is a necessity for success and survival in today's competitive world (Khenget al., 2010). Banks do business with customer's money. So, the more satisfied customers are involved in a bank's row, the more secure business and profitability. If a bank cannot provide proper customer service, then the bank would be losing its customers. The profitability would also be decreasing because of the poor customer service. According to Kang (2004) many service delivery errors and problems can occur and that is not beneficial for the reputation of the organization. Ha and Jang (2009) argued that service failure occurs when customer perceptions do not meet customer expectations. In order to achieve customer satisfaction, organizations must be able to build and maintain long lasting relationships with customers through satisfying various customers needs and demands (Pizam\& Ellis, 1999). Otherwise, the combined effect of negative word-of-mouth, switching and reduced consumption will affect the productivity and profitability of the bank. This study makes an attempt to answer the questions such as; what is the relationship between banks' service and Bank's Customer Satisfaction? What is the impact of service quality on customer satisfaction in the commercial banks of Nepal in terms of service dimensions: Tangibility, Reliability, Responsiveness, Assurance and Empathy? Does the financial performance is sound in selected organizations whereas the main research objectives of the study are;

- To examine the relationship between Banks' Service Quality and Bank's Customer Satisfaction.

- To determine the impact of service quality on customer satisfaction in the commercial banks of Nepal in terms of service dimensions: Tangibility, Reliability, Responsiveness, Assurance and Empathy.

- To examine the financial performance in terms of ROA and ROE of selected banks.

\section{Literature Review}

Service quality has received a great deal of attention from both academicians and practitioners (Negi, 2009) and service marketing literature defined service quality as the overall assessment of a service by the customer (Eshghiet al., 2007). Duff et al. (2008) pointed out that, by defining service quality, companies will be able to deliver services with higher quality level presumably resulting in increased customer satisfaction. Akroush (2008) also pointed out that service quality is the result of the comparison made by customers about what they feel service firms should offer, and perceptions of the performance of firms providing the services. Gronroos (2007) also defined service quality as the outcome of the comparison that consumers make between their expectations and perceptions. It is very vital to note here that, service quality is not only assessed 
as the end results but also on how it is delivered during service process and its ultimate effect on consumer's perceptions (Duncan \& Elliot, 2004). Service quality has a strong correlation with customer satisfaction, financial performance, manufacturing costs, customer retention, customer loyalty, and the success of marketing strategy (Cronin et al., 2000; Wong et al., 2008). Through service quality, organizations can reach a higher level of service quality, a higher level of customer satisfaction, and can maintain a constant competitive advantage (Meuteret al., 2000).

In the changing banking scenario of 21 st century, the banks should have a vital identity to provide excellent services. Banks nowadays have to be of world-class standard, committed to excellence in customer's satisfaction and to play a major role in the growing and diversifying financial sector (Guoet al., 2008). There has been a remarkable change in the way of banking in the last few years. Banking industry is a demand driven industry, which constitute an important part of the service industry (Newman \& Cowling, 1996). Banks have to redefine their corporate image that emphasizes service quality since it provides many advantages to a company such as allowing the company to differentiate itself from its competitors by increasing sales and market shares, providing opportunities for cross selling, improving customer relations thus enhancing the corporate image, reliability, responsiveness, credibility and communication results in the satisfaction and retention of customers and employee, thus reducing turnover rate (Newman, 2001).

In line with Tsoukatos and Rand (2006), customer satisfaction is a key to long-term business success. To protect or gain market shares, organizations need to outperform competitors by offering high quality product or service to ensure satisfaction of customers. In proportion to Magesh (2010), satisfaction means a feeling of pleasure because one has something or has achieved something. It is an action of fulfilling a need, desire, demand or expectation. Customers compare their expectations about a specific product or services and its actual benefits. As stated by Kotler\& Armstrong, (2010), satisfaction is a person's feelings of pleasure or disappointment resulting from the comparison of product's perceived performance in reference to expectations. Customer's feelings and beliefs also affect their satisfaction level. Along with Zeithaml (2009), satisfaction or dissatisfaction is a measure or evaluation of a product or service's ability to meet a customer's need or expectations. Razak et al. (2007) also reported that overall satisfaction is the outcome of customer's evaluation of a set of experiences that are linked with the specific service provider. It is observed that organization's concentration on customer expectations is resulted into greater satisfaction. If the customers of an organization are satisfied by their services the result is that, they will be loyal to them and consequently be retained by the organization, which is positive for the organization because it could also mean higher profits, higher market share, and increasing customer base (Karatepeet al., 2005).

Customer satisfaction has become important due to increased competition as it is considered very important factor in the determination of bank's competitiveness (Berry et al., 2002). Continuous measurement of satisfaction level is necessary in a systematic manner (Chakravartyet al., 1996). Because satisfied customer is the real asset for an organization that ensures long-term profitability even in the era of great competition. Cronin et al., (2000) mentioned in their study that satisfied customer repeats his/her experience to buy the products and also creates new customers by 
communication of positive message about it to others. On the other hand, dissatisfied customer may switch to alternative products/services and communicate negative message to others. Customer satisfaction is a set of feeling or outcome attached with customer's experience towards any product/ service (Solomon, 1998). Hence, organizations must ensure the customer satisfaction regarding their goods/services.

Quality and customer satisfaction have long been recognized as playing a crucial role for success and survival in today's competitive market. Regarding the relationship between customer satisfaction and service quality, Oliver (1993) first suggested that service quality would be antecedent to customer satisfaction regardless of whether these constructs were cumulative or transaction-specific. In relation to the customer satisfaction and service quality, researchers have been more precise about the meaning and measurements of satisfaction and service quality. Satisfaction and service quality have certain things in common, but satisfaction generally is a broader concept, whereas service quality focuses specifically on dimensions of service (Wilson et al., 2008). Although it is stated that other factors such as price and product quality can affect customer satisfaction, perceived service quality is a component of customer satisfaction (Zeithaml\&Bitner, 2003).

The most widely used models in measuring service quality in the banking sector are the SERVQUAL and SERVPERF models. According to the SERVQUAL model (Parasuraman et al., 1988), service quality can be measured by identifying the gaps between customer's expectations of the service to be rendered and their perceptions of the actual performance of the service. SERVQUAL is based on five dimensions of service quality (Parasuraman et al., 1988):

Tangibles: the physical surroundings represented by objects (for example, interior design) and subjects (for example, the appearance of employees).

Reliability: the service provider's ability to provide accurate and dependable services.

Responsiveness: a firm's willingness to assist its customers by providing fast and efficient service performances.

Assurance: diverse features that provide confidence to customers (such as the firm's specific service knowledge, polite and trustworthy behavior of employees).

Empathy: the service firm's readiness to provide each customer with personal approach.

\section{The Data and Methodology}

\subsection{Research Design and Sample Size}

The target population identified for gathering information regarding this concern is Nepalese Commercial Banks. There were 31 banks at the time of the study. Out of these 31 banks only 17 numbers of banks were established before 2002. The selection of the bank for the study was framed on the basis of ten years in operations. Furthermore, six earliest established Nepalese 
commercial banks were selected for the study. These banks were established between 1937 and 1993. In the sampling framework, samples of customers of these banks were taken for the study. The samples of banks were done with stratified sampling method. This stratification of population resulted into sampling frame of six banks namely, Nepal Bank Ltd. Kathmandu (1937), Rastriya Banijya Bank Ltd. Kathmandu (1966), Nabil Bank Ltd. Kathmandu (1984), Nepal Investment Bank Ltd. Kathmandu (1986), Standard Chartered Ltd. Kathmandu (1986), and Himalayan Bank Ltd. Kathmandu (1993). However, one bank ADB was a pseudo commercial bank; hence it was not considered for the study. The criteria used in selecting the banks were comparable size and operating environment as far as practicable. For the purpose of data collection from the customers, a random sampling of 100 customers each sampled commercial bank has been undertaken. The decided number of questionnaires was distributed randomly to the customer with a minimum expected rate of return of 50\%. However, out of the distributed 600 customers' questionnaire, total of 392 questionnaires were returned. Henceforth, the response rate was $65.33 \%$ in total. Whereas, the individual response rate for customers of different banks were Nepal Bank Ltd. of $75 \%$; Rastriya Banijya Bank Ltd. of 55\%; Nabil Bank Ltd. of 79\%; Nepal investment Bank Ltd. of $63 \%$; Standard chartered Ltd. of $60 \%$; and Himalayan Bank Ltd. of $60 \%$.

Table 1: Detail of Sample and response rate

\begin{tabular}{|l|c|c|c|}
\hline Banks & $\begin{array}{c}\text { Questionnaire } \\
\text { Distributed }\end{array}$ & $\begin{array}{c}\text { Actual Questionnaire } \\
\text { Returned }\end{array}$ & $\begin{array}{c}\text { Response } \\
\text { Rate }\end{array}$ \\
\hline Nepal Bank Ltd. & 100 & 75 & 75.00 \\
\hline Rastriya Banijya Bank Ltd. & 100 & 55 & 55.00 \\
\hline Nabil Bank Ltd. & 100 & 79 & 79.00 \\
\hline Nepal investment Bank Ltd. & 100 & 63 & 63.00 \\
\hline Standard chartered Ltd. & 100 & 60 & 60.00 \\
\hline Himalayan Bank Ltd. & 100 & 60 & 60.00 \\
\hline Total & $\mathbf{6 0 0}$ & $\mathbf{3 9 2}$ & $\mathbf{6 5 . 3 3}$ \\
\hline
\end{tabular}

Source: Survey, 2015

\subsection{Data Collection Procedures}

Keeping in view of the objectives, this study based on primary sources with questionnaire survey. At the outset, the independent variables of Quality of Service include Tangibility, Responsiveness, Reliability, Empathy and Assurance. Likewise, the variables of Overall satisfaction include single opinion statement. Van de Ven and Ferry (1980) that assessed satisfaction with the respondent's present position on a 5-point scale. While the internal consistency reliability of a single -item measures cannot be evaluated, research suggests such items are stable and reproducible and may reflect satisfaction more accurately than many facet measures (Scarpello \& Campbell, 1983). The questionnaire includes 20 opinion statements. The 19 statements are developed under the five main variables with relevant literatures review that includes Tangibility, Responsiveness, 
Reliability, Empathy and Assurance. Likewise 1 opinion statement is put for Overall Satisfaction and 5 point scale has been used.

\subsection{Reliability of Scale}

The Cronbach's $\alpha$ for Total Quality Service was 0.915 which is highly reliable. Likewise, tangibility, empathy, Responsiveness, Assurance and Reliability has 0.794, 0.719, 0.721, 0.782 and 0.787 respectively. While the internal consistency of Overall Satisfaction which was measured with one opinion statement. Thus, the reliability of a single -item measures cannot be evaluated.

Table 2 : Reliability Statistics for Customer Satisfaction questionnaire

\begin{tabular}{|l|l|c|c|}
\hline Sl. No. & Variables & Cronbach's Alpha & N of Items \\
\hline $\mathbf{1}$ & Total Quality Service & $\mathbf{0 . 9 1 5}$ & $\mathbf{1 9}$ \\
\hline 1a & Tangibility & 0.794 & 3 \\
\hline 1b & Empathy & 0.719 & 4 \\
\hline 1c & Responsiveness & 0.721 & 4 \\
\hline 1d & Assurance & 0.782 & 3 \\
\hline 1e & Reliability & 0.787 & 5 \\
\hline
\end{tabular}

Source: Survey 2015

\section{Data Analysis and Presentation}

\subsection{Primary Data Analysis}

\subsubsection{Characteristics of banks' customers}

There are total of 392 respondents in customers. Out of the total sample, the sample of 224 respondents comprise $57.1 \%$ males and $42.9 \%$ females comprised of 168 nos. There are 226 nos. $(57.7 \%)$ are under the age-group of $18-30$ years, 149 (38\%) are under the age group of 31-50 years and 17 nos. $(4.3 \%)$ are in the group of 51 years and above. Majority of the respondents falls within the +2 or bachelor's level with 236 nos. (60.2\%) representations, Master's level educational status with 112 nos. (28.2\%) representations, 30 nos. $(7.7 \%)$ in SLC and below and 14 nos. (3.6\%) in M. Phil. level. At the time of study, the respondents were banking with the following; Himalayan Bank Limited 60 nos. (15.3\%), NABIL Bank 79 nos. (20.2\%), Nepal Bank Limited 75 nos. (19.1\%), Nepal Investment Bank Ltd. 63 nos. (16.1\%), Rastriya Banijya Bank55 nos. (14\%) and Standard Chartered Bank 60 nos. (15.3\%). Similarly, the customers have varying banking transaction frequency. Out of the total respondents, most of them have monthly transaction with 181 nos. (46.2\%), 145 nos. (37\%) have weekly transactions, 16 nos. (4.1\%) have daily transactions and 50 nos. (12.8\%) have a mixed transaction. 
Table 3: Demographic characteristics of customer respondents

\begin{tabular}{|c|c|c|c|c|c|c|c|c|c|}
\hline $\begin{array}{l}\text { Sl. } \\
\text { No. }\end{array}$ & Attributes & Sub Attributes & $N$ & $\%$ & $\begin{array}{l}\text { Sl. } \\
\text { No. }\end{array}$ & Attributes & Sub Attributes & $N$ & $\%$ \\
\hline & & Male & 224 & 57.1 & \multirow{4}{*}{3} & \multirow{4}{*}{$\begin{array}{l}\text { Education } \\
\text { Level }\end{array}$} & SLC or Below & 30 & 7.7 \\
\hline 1 & fuender & Female & 168 & 42.9 & & & +2 or Bachelor & 236 & 60.2 \\
\hline \multirow{3}{*}{2} & \multirow{3}{*}{$\begin{array}{l}\text { Age } \\
\text { Group }\end{array}$} & $18-30$ & 226 & 57.7 & & & Post Graduate & 112 & 28.6 \\
\hline & & $31-50$ & 149 & 38 & & & M.Phil/ PhD & 14 & 3.6 \\
\hline & & 51 and above & 17 & 4.3 & \multirow{4}{*}{5} & \multirow{4}{*}{$\begin{array}{l}\text { Banking } \\
\text { transaction } \\
\text { frequency }\end{array}$} & Daily & 16 & 4.1 \\
\hline \multirow{6}{*}{4} & \multirow{6}{*}{ Banks } & Nabil Bank & 79 & 20.2 & & & Weekly & 145 & 37 \\
\hline & & Himalayan Bank & 60 & 15.3 & & & Monthly & 181 & 46.2 \\
\hline & & Rastriya Banijya & 55 & 14 & & & Other & 50 & 12.8 \\
\hline & & Nepal Bank & 75 & 19.1 & & & & & \multirow{3}{*}{$N=392$} \\
\hline & & $\begin{array}{l}\text { Nepal } \\
\text { Investment bank }\end{array}$ & 63 & 16.1 & & & & & \\
\hline & & $\begin{array}{l}\text { Standard } \\
\text { Chartered }\end{array}$ & 60 & 15.3 & & & & & \\
\hline
\end{tabular}

Source: Survey, 2015

\subsubsection{Overall Customers'Satisfaction towards quality service}

The overall customers' satisfaction is measured with one opinion statement. The mean overall customers' satisfaction is 3.55 ( $\mathrm{SD}=0.897)$, which shows a moderate agreeableness towards satisfaction. However, the result shows that the satisfaction level of the customers is a concern; they do not perceive that they are satisfied highly towards the quality service of the banks. Table 4, presents the detail of Overall Customer Satisfaction towards total quality service of commercial banks. The values are significant at $1 \%$ level.

Table 4 : Overall Customer Satisfaction towards total quality service

\begin{tabular}{|l|c|c|c|c|r|l|}
\hline \multirow{2}{*}{ Opinion Statement } & \multirow{2}{*}{ Mean } & SD & \multicolumn{4}{|c|}{ Test-Value =3 } \\
\cline { 4 - 7 } & & & $\mathbf{t}$ & $\mathbf{d f}$ & $\begin{array}{c}\text { Sig. } \\
\text { (2-tailed) }\end{array}$ & Remarks \\
\hline $\begin{array}{l}\text { Customer satisfaction towards } \\
\text { service quality }\end{array}$ & 3.554 & .897 & 12.213 & 391 & 0.001 & Significant \\
\hline
\end{tabular}

\subsubsection{Perception of banking customers towards total quality service}

This section presents the dimension of the Total Quality Service by the commercial banks. The total quality of the banking service is perceived by the customers in 5 variables namely empathy, assurance, reliability, responsiveness and tangibility.The total mean value of the factors of the total quality service (empathy, assurance, reliability, responsiveness and tangibility) is $3.39(\mathrm{SD}=0.602)$ and seems to be agreeing that customer satisfaction is moderately satisfactory. It is highly significant at $1 \%$ level of significance. Therefore, there is a strong relationship 
between service quality and customer satisfaction. Hence, it may be deduced that quality service affects customer satisfaction. Similarly, the dimensions of the overall quality service have the following mean value; Tangibility $3.61(\mathrm{SD}=.744)$, Empathy $3.38(\mathrm{SD}=.745)$, Responsiveness 3.41 ( $\mathrm{SD}=.722)$, Assurance 3.10 ( $\mathrm{SD}=.910)$, and Reliability $3.47(\mathrm{SD}=.729)$. These results have moderately agreeableness to the quality dimensions. It is highly significant at $1 \%$ level of significance. Table 5 puts details of quality dimensions.

Table 5 : Respondents' view on Total Quality Service and Overall Satisfaction

\begin{tabular}{|l|r|r|r|r|r|r|}
\hline \multirow{2}{*}{ Variables } & \multirow{2}{*}{ N } & \multirow{2}{*}{ Mean } & \multirow{2}{*}{\begin{tabular}{c}
\multirow{2}{*}{ Std. } \\
Deviation
\end{tabular}} & \multicolumn{3}{|c|}{ Test Value=3 } \\
\cline { 7 - 8 } & & & & t value & \multicolumn{1}{c|}{ p value } & \multicolumn{1}{c|}{ Remarks } \\
\hline Tangibility & 392 & 3.618 & 0.745 & 16.431 & 0.001 & Significant \\
\hline Empathy & 392 & 3.380 & 0.746 & 10.091 & 0.001 & Significant \\
\hline Responsiveness & 392 & 3.416 & 0.723 & 11.388 & 0.001 & Significant \\
\hline Assurance & 392 & 3.101 & 0.911 & 2.191 & 0.029 & Significant \\
\hline Reliability & 392 & 3.476 & 0.729 & 12.928 & 0.001 & Significant \\
\hline Total Quality Service & 392 & 3.398 & 0.602 & 13.099 & 0.001 & Significant \\
\hline
\end{tabular}

Source: Survey, 2015

\subsubsection{Dimension of service quality and Customers'Satisfaction}

The results as presented in table. 6 , indicate that there is a moderate to strong relationship between the Service Quality variables and Customers' total satisfaction on banks' service quality. The range for correlation Customers' Satisfaction on Total Quality Service with the Overall Service Quality of the bank have $r(507)=0.639,(p<0.01)$, according to Rubin's (2010) scale for correlation coefficients, the relationship is strong correlation.

Table 6 : Correlation between Customer's Satisfaction with the Overall Service Quality

\begin{tabular}{|l|l|r|r|}
\hline \multicolumn{2}{|l|}{ Variables } & \multicolumn{1}{c|}{ Remarks } \\
\hline $\begin{array}{l}\text { Total Quality Service Satisfaction to } \\
\text { Overall Service Quality of the bank. }\end{array}$ & $r$ & $\mathrm{r}=.639^{* *}$ & Strong correlation \\
\cline { 2 - 5 } & $p$ & $\mathrm{p}=0.001$ & Significant \\
\hline $\begin{array}{l}\text { **. Correlation is significant at the 0.01 level (2-tailed). } \\
\text { N=392 }\end{array}$ & \\
\hline
\end{tabular}

To explore further, there is also moderate to strong relationship between the Overall customers' satisfaction with Service Quality and dimensions of Total Quality Service Satisfaction.

Tangibility $r(392)=0.471,(p<0.01)$, Empathy $r(392)=0.477,(p<0.01)$, Responsiver $(392)=$ $0.474,(\mathrm{p}<0.01)$, Assurance $\mathrm{r}(392)=0.493,(\mathrm{p}<0.01)$, Reliability $r(392)=0.583,(\mathrm{p}<0.01)$, all of the variables having moderate to strong correlation to each other except Reliability have a strong relationship and all variables are statistically significant at 0.01 level. 
Table 7: Overall customer's satisfaction and Total Quality Service Satisfaction

\begin{tabular}{|l|l|c|l|}
\hline \multicolumn{2}{|c|}{$\begin{array}{c}\text { Dimensions of Service Quality } \\
\text { in Banks }\end{array}$} & $\begin{array}{c}\text { Overall satisfaction with } \\
\text { service quality of the bank }\end{array}$ & \multicolumn{1}{c|}{ Remarks } \\
\hline \multirow{2}{*}{ Tangibility } & $r$ & $.471^{* *}$ & Moderate to Strong correlation \\
\cline { 2 - 4 } & $p$ & .001 & Significant \\
\hline \multirow{2}{*}{ Empathy } & $r$ & $.477^{* *}$ & Moderate to Strong correlation \\
\cline { 2 - 4 } & $p$ & .001 & Significant \\
\hline \multirow{2}{*}{ Responsive } & $r$ & $.474^{* *}$ & Moderate to Strong correlation \\
\cline { 2 - 4 } & $p$ & .001 & Significant \\
\hline \multirow{2}{*}{ Assurance } & $r$ & $.493^{* *}$ & Moderate to Strong correlation \\
\cline { 2 - 4 } & $p$ & .001 & Significant \\
\hline \multirow{2}{*}{ Reliability } & $r$ & $.583^{* *}$ & Strong correlation \\
\cline { 2 - 5 } & $p$ & .001 & Significant \\
\hline
\end{tabular}

$* *$ Correlation is significant at the 0.01 level (2-tailed). $\mathrm{N}=392$

\subsubsection{Hypothesis Testing}

The result of correlation analysis represents statistically significant positive relationship between Tangibility and Overall Customers' Satisfaction. It is statistically significant with $r(392)=0.471$, $(p<0.01)$. Hence, the null hypothesis $\left(\mathrm{HO}_{\mathrm{P}}\right)$ is rejected.

The result of correlation analysis represents statistically significant positive relationship between Reliability and Overall Customers' Satisfaction. It is statistically significant with $r(392)=0.583$, $(\mathrm{p}<0.01)$. Hence, the null hypothesis $\left(\mathrm{HO}_{2}\right)$ is rejected.

The result of correlation analysis represents statistically significant positive relationship between Responsiveness and Overall Customers' Satisfactions. It is statistically significant with $r(392)=$ 0.474 , $(\mathrm{p}<0.01)$. Hence, the null hypothesis $\left(\mathrm{HO}_{3}\right)$ is rejected.

The result of correlation analysis represents statistically significant positive relationship between Assurance and Overall Customers' Satisfaction. It is statistically significant with $\mathrm{r}(392)=0.493$, $(\mathrm{p}<0.01)$. Hence, the null hypothesis $\left(\mathrm{HO}_{4}\right)$ is rejected.

The result of correlation analysis represents statistically significant positive relationship between Empathy and Overall Customers' Satisfaction. It is statistically significant with $r(392)=0.477$, $(p<0.01)$. Hence, the null hypothesis $\left(\mathrm{HO}_{5}\right)$ is rejected.

The result of correlation analysis represents statistically significant positive relationship between Total Service Quality and Overall Customers' Satisfaction. It is statistically significant with $r$ $(507)=0.639,(p<0.01)$. Hence, the null hypothesis $\left(\mathrm{HO}_{6}\right)$ is rejected.

\subsubsection{Contribution of Banks'Service Quality towards Customers'Satisfaction}

Since the relationship between Banks' Service Quality to Customer Satisfaction has been established in this study, further, this study has also focused on examining the effect of changes in Banks' Service Quality on Customer Satisfaction. Tables 8 \& 9, summarize the model. The result 
shows that there is a significant impact of Banks' Service Quality on Customers' satisfaction. It signifies that a change in Banks' Service Quality will improve Customers' satisfaction. It shows a significant association between the changes of Banks' Service Quality on Customers' satisfaction. The finding of multiple regression analysis indicates significant predictability of Banks' Service Quality over Overall Customers' satisfaction. The $R$ value of 0.756 indicates the moderate to strong positive relationship between Service quality and Overall Customer satisfaction $(\mathrm{F}=58.291$, $\mathrm{p}<0.01)$. Similarly $R$-square value of 0.530 states that $53 \%$ change in performance is due to combined independent variables. Likewise, Standard error of the estimate of 0.481 indicates the variability of the observed value of Overall Customer satisfaction from regression line is 0.481 units. Since VIF of each of independent variables is less than 10, there is no problem of multicolinearity in this model. Thus, it is shown that there is significant correlation between Service quality and significantly predict Overall Customer satisfaction. All the variables of Service quality are significantly influencing the dependent variable Overall Customers' satisfaction. The variable of Banks' Service Quality significantly contributes into following ways, viz.- Tangibility has 13.2\%, Empathy has $12.2 \%$, Responsiveness has $14.6 \%$, Assurance has $26.1 \%$, Reliability has $38.3 \%$ predictability respectively. Likewise, $t$-value of the coefficient and their significance levels are reported in table. It is observed that the $t$-values of two variables are statistically significant at $1 \%$ level viz, Assurance and Reliability. Similarly, it is observed that the $t$-values of three variables are statistically significant at 5\% level viz, Tangibility, Empathy and Responsiveness.

Table 8: Model Summary of Banks' Total Service Quality to Customers' Satisfaction

\begin{tabular}{|c|c|c|c|c|c|c|c|}
\hline \multicolumn{6}{|c|}{ Table 8 : Model Summary ${ }^{b}$} & \multirow[b]{2}{*}{$\mathbf{F}$} & \multirow[b]{2}{*}{ p value } \\
\hline Model & $\mathbf{R}$ & R Square & $\begin{array}{c}\text { Adjusted R } \\
\text { Square }\end{array}$ & $\begin{array}{l}\text { Std. Error of } \\
\text { the Estimate }\end{array}$ & $\begin{array}{l}\text { Durbin- } \\
\text { Watson }\end{array}$ & & \\
\hline 5 & $.756^{\mathrm{a}}$ & .530 & .523 & .48175 & 1.851 & 58.291 & .001 \\
\hline
\end{tabular}

Table 9: Multiple Regression Analysis : Coefficients ${ }^{\mathrm{a}}$

\begin{tabular}{|l|r|r|r|r|r|r|r|}
\hline \multirow{2}{*}{ Model-5 } & \multicolumn{2}{|c|}{$\begin{array}{c}\text { Unstandardized } \\
\text { Coefficients }\end{array}$} & $\begin{array}{c}\text { Standardized } \\
\text { Coefficients }\end{array}$ & \multirow{2}{*}{$\mathrm{t}$} & \multirow{2}{*}{ Sig. } & \multicolumn{2}{|c|}{$\begin{array}{c}\text { Collinearity } \\
\text { Statistics }\end{array}$} \\
\cline { 2 - 4 } \cline { 7 - 9 } & \multicolumn{1}{c|}{$\mathrm{B}$} & Std. Error & \multicolumn{1}{c|}{ Beta } & & & Tolerance & VIF \\
\hline (Constant) & 0.364 & 0.2 & & 1.818 & 0.07 & & \\
\hline Tangibility (X1) & 0.132 & 0.063 & 0.109 & 2.085 & 0.038 & 0.537 & 1.86 \\
\hline Empathy (X2) & 0.122 & 0.071 & 0.102 & 1.733 & 0.044 & 0.429 & 2.332 \\
\hline Responsiveness (X3) & 0.146 & 0.077 & 0.037 & 0.605 & 0.046 & 0.385 & 2.594 \\
\hline Assurance (X4) & 0.261 & 0.043 & 0.265 & 6.078 & 0.001 & 0.775 & 1.291 \\
\hline Reliability (X5) & 0.383 & 0.072 & 0.311 & 5.295 & 0.001 & 0.427 & 2.341 \\
\hline
\end{tabular}


From the above, the estimated equation can be written by taking the values from the model:

$\hat{Y}=\alpha+\beta_{1} X_{1}+\beta_{2} X_{2}+\beta_{3} X_{3}+\beta_{4} X_{4}+\beta_{5} X_{5}+e_{i}$

Therefore, $\hat{\mathrm{Y}}=0.364+0.132 * X_{1}+0.122 * X_{2+} 0.146 * X_{3+} 0.261 * X_{4+} 0.383 * X_{5}$

\subsection{Secondary Data Analysis}

\subsubsection{Return on assets}

ROA is primarily an indicator of managerial efficiency. It indicates how the management of the bank is capable of converting the institution's asset into net earnings. ROA is expressed as a ratio of net income (net profit after tax) and total assets of a bank. The figures of ROA of the six banks are shown in table 4.69. The figures show a fluctuated ROA over the years from 2003/04 to 2012/13. It is observed that the asset of the bank, fluctuating in the study period (from 2003/04 to 2012/13) at an increasing rate but relatively the banks are unable to generate more profit from the incremental asset. On an average within the study period, the banks have following mean valueNBL has a mean value of 1.47; RBB has a mean value of 2.69; NABIL has a mean value of 2.56; NIBL has a mean value of 1.79; SCBN has a mean value of 2.53; and HBL has a mean value of 1.53.Individually, RBB has the highest return on its assets within the study period, whereas, NBL has the lowest performance of all. Likewise, NBL has highest returns in 2004/05 with ROA of 3.68, RBB has highest returns in 2005-06 with ROA of 3.99, NABIL has highest returns in 2012-13 with ROA of 3.03, NIBL has highest returns in 2012-13 with ROA of 2.62, SCBN has highest returns in 2012-13 with ROA of 2.8, HBL has highest returns in 2012-13 with ROA of 1.91. The ROA figures show that the performance of banks in generating returns on their assets is not satisfactory. HBL has seemed the second worst performer in regard of ROA. Out of the six commercial banks NBL has a more fluctuating ROA, a drastic fall in ROA can be seen from 200506 to 2006-07. Likewise, a fall in ROA from 2008-09 till 2011-12 can be seen. However, ROA is recovered in 2012-13. Similarly, RBB has a gradual increase in ROA till 2005-06 from 2003-04. However, a relevant slowdown of ROA from 2005-06 till 2012-13 makes RBB a worst performer in terms of ROA. Other banks have stagnancy in performance in ROA which ranges from a value of ROA of 3 to 1 . The detail performance figures of ROA can be seen at table 10 below.

Table 10: Analysis of Return on Assets (ROA) of various commercial banks in Nepal

\begin{tabular}{|c|c|c|c|c|c|c|c|c|c|c|c|c|c|}
\hline \multirow[b]{2}{*}{$\begin{array}{l}\text { Sl. } \\
\text { No. }\end{array}$} & \multirow[b]{2}{*}{ Banks } & \multicolumn{10}{|c|}{ Financial Year (results in percentage) } & \multirow[b]{2}{*}{$\sum_{\Sigma}^{E ్ ~}$} & \multirow[b]{2}{*}{ \% } \\
\hline & & 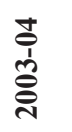 & 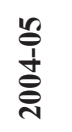 & 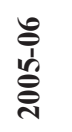 & 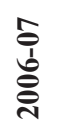 & 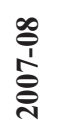 & 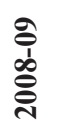 & $\begin{array}{l}\stackrel{\ominus}{1} \\
\text { ᄋ̆ } \\
\text { ㄱ }\end{array}$ & 클 & $\frac{\mathfrak{I}}{\stackrel{7}{\overrightarrow{7}}}$ & $\frac{m}{\stackrel{3}{I}}$ & & \\
\hline 1 & $N B L$ & 1.61 & 3.68 & 3.36 & 0.58 & 0.57 & 1.88 & 1 & 0.73 & 0.3 & 1.07 & 1.47 & 1.18 \\
\hline 2 & $R B B$ & 2.31 & 3.76 & 3.99 & 3.5 & 3.32 & 2.8 & 2.39 & 2.17 & 1.44 & 1.29 & 2.69 & 0.93 \\
\hline 3 & NABIL & 2.72 & 3.02 & 2.84 & 2.47 & 2.01 & 2.35 & 2.19 & 2.31 & 2.68 & 3.03 & 2.56 & 0.35 \\
\hline 4 & $N I B L$ & 1.15 & 1.43 & 1.64 & 1.82 & 1.79 & 1.7 & 2.21 & 2.02 & 1.58 & 2.62 & 1.79 & 0.41 \\
\hline 5 & $S C B N$ & 2.27 & 2.43 & 2.56 & 2.42 & 2.46 & 2.53 & 2.7 & 2.55 & 2.8 & 2.67 & 2.53 & 0.15 \\
\hline 6 & $H B L$ & 1.06 & 1.17 & 1.55 & 1.47 & 1.76 & 1.91 & 1.19 & 1.91 & 1.76 & 1.54 & 1.53 & 0.31 \\
\hline
\end{tabular}




\subsubsection{Return on equity}

The return on equity ratio shows the percentage of net income to total capital of the bank. The higher the ratio the more efficiently a bank is using its capital and free reserves. The greater the percentage of ROE, the better efficiency the bank possess as the ratio is composed of profit margin, degree of asset utilization and equity multiplier. The analysis of ROE figures from 200304 to $2012-13$, the ROE ranged from $-56.64 \%$ to $162.5 \%$ over the study period. The mean ROE ranges for the six samples banks are $-8.66 \%$ and $42.44 \%$. According the ROE, the performance of NABIL is better than other commercial banks, whereas, the worst performer in terms of ROE is RBB. On an average within the study period, the banks have following mean value- NBL has a mean value of 12.82 ; RBB has a mean value of -8.66 ; NABIL has a mean value of 42.44 ; NIBL has a mean value of 35.52; SCBN has a mean value of 42.18; and HBL has a mean value of 29.59. Individually, NABIL has the highest return of net income to total capital of the bank. Whereas, RBB has the lowest performance of all. Likewise, NIBL has increased its ROE from $27.4 \%$ in $2003 / 04$ and to $35.52 \%$ in the final year. NABIL also increased by $22.33 \%$ but unfortunately NBL and RBB decreased their ROE by $149.96 \%$ and $184.82 \%$ respectively in the final year of the study period. Out of the six commercial banks NBL has a more fluctuating ROE, a sharp fall in ROE can be seen from 2004-05 to 2005-06, and it decreases till it reaches to negative figures in 2012-2013. Likewise, RBB has a fall in ROE since 2003-04 till 2012-13. However, there is a sharp decrease in 2004-05 and 2012-13. Similarly, other banks have a moderate fluctuation in its ROE, which ranges in between 0 to $50 \%$. With this, NBL and RBB are the worst performer within the study detail performance figures of ROE can be seen at table 11 below.

Table 11: Analysis of Return on Equity (ROE) of various commercial banks in Nepal

\begin{tabular}{|c|c|c|c|c|c|c|c|c|c|c|c|c|c|}
\hline \multirow[b]{2}{*}{$\begin{array}{l}\dot{0} \\
\dot{z} \\
\dot{\vec{\Omega}}\end{array}$} & \multirow[b]{2}{*}{ 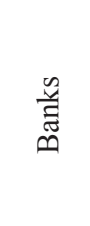 } & \multicolumn{10}{|c|}{ Financial Year (results in percentage) } & \multirow[b]{2}{*}{ 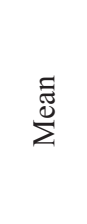 } & \multirow[b]{2}{*}{ ڤิ } \\
\hline & & 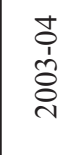 & 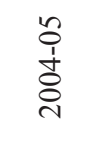 & 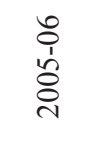 & 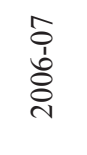 & 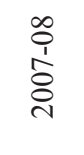 & $\begin{array}{l}\text { oे } \\
\text { 1 } \\
\text { ᄋ̊ } \\
\text { ㄱ. }\end{array}$ & $\begin{array}{l}\frac{0}{1} \\
\text { ò } \\
\text { } \\
\text { ㄱ. }\end{array}$ & 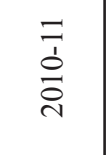 & $\frac{\stackrel{\sim}{1}}{\stackrel{1}{\circ}}$ & $\begin{array}{l}\frac{m}{1} \\
\stackrel{1}{\Xi} \\
\stackrel{\sim}{N}\end{array}$ & & \\
\hline 1 & $N B L$ & 49 & 162.55 & -11.66 & -2.26 & -3.95 & -16.56 & -5.02 & -15.56 & -3.82 & -24.48 & 12.82 & 56.26 \\
\hline 2 & $R B B$ & 66.78 & -5.55 & -7.42 & -7.97 & -9.62 & -11.17 & -15.13 & -20.42 & -19.48 & -56.64 & -8.66 & 30.38 \\
\hline 3 & $N A B I L$ & 39.72 & 28.75 & 42.85 & 40.66 & 39.82 & 50.12 & 46.74 & 42.95 & 44.22 & 48.59 & 42.44 & 5.8 \\
\hline 4 & NIBL & 27.4 & 31.34 & 28.39 & 43.29 & 50.83 & 45.97 & 37 & 31.25 & 22.66 & 37.1 & 35.52 & 8.98 \\
\hline 5 & $S C B N$ & 48.06 & 35.29 & 51.54 & 43.88 & 46.65 & 48.42 & 43.55 & 36.66 & 34.67 & 33.12 & 42.18 & 6.68 \\
\hline 6 & $H B L$ & 35.52 & 22.65 & 34.44 & 31.9 & 36 & 35.07 & 20.25 & 28.63 & 27.87 & 23.62 & 29.59 & 5.87 \\
\hline
\end{tabular}

\section{Concluding Remarks}

The banking sector is the most prominent one in the financial sector; it is the fastest growing sector in Nepal in the last two decades. Financial liberalization and technological revolution intensify the competitive pressures among the financial institutions. Well-designed service quality and customer satisfaction can more effectively and efficiently lead an organization towards higher performance. 
As stated from the analysis, it is clear that Customers' Satisfaction depends on the dimensionality of Service Quality. Thematic point of the study indicates that the mean of overall Customers' Satisfaction in Nepalese Commercial Banks has moderate level. However, the result indicates the satisfaction level of the customers is a concern; they do not perceive that they are satisfied highly towards the quality service of the banks. The results also indicate that there is a significant relation of the dimension of quality service and overall customers' satisfaction. Results of correlation analysis show significant relationship amongst of all the variables at $p<.01$. The result of the regression analysis shows that the model of five variables in both sectors has an impact on Customers' Satisfaction. The model has R-square value indicates that 53\% change in Customers' Satisfaction due to combined independent variables. Likewise, the variable of Banks' Service Quality significantly contributes into following ways, viz.- Tangibility has $13.2 \%$, Empathy has $12.2 \%$, Responsiveness has 14.6\%, Assurance has 26.1\%, Reliability has 38.3\% predictability respectively. It can be interpreted from the regression analysis. It is in support with the studies such as Karim and Chowdhury (2014), Chan (2008), Appannan, Doraisamy\&Hui (2013) and others. Service quality and customers' satisfaction are considered an important tools for a firm's struggle to itself (Banks) from its competitors (Ladhari, 2008). Similarly, Service quality has a strong correlation with customer satisfaction, and the success of organization (Cronin et al., 2000; Wong et al., 2008). Through service quality, organizations can reach a higher level of service quality, a higher level of customer satisfaction, and can maintain a constant competitive advantage ( Meuteret al., 2000). As obtained in the result, all of hypothesizes postulated are accepted which resembles that the service quality of the banks, comprises of 5 dimensions and aligned with previous studies on the subject. Therefore, several steps should be taken by the Nepalese Commercial banks to enhance their service quality to stay marketed, maintain a premium position at the top and to compete with other as well. The findings of this study is contradictory with the study done by Karatepe et.al (2005) Kheng, et al (2010) and,Sureshchandar, (2002).

The performance of ROA of the six banks was fluctuated over the years from 2003/04 to 2012/13. Wherein the banks were unable to generate more profit from the incremental asset. NBL has the lowest performance of all. Likewise, RBB has highest returns in 2005-06, NABIL has highest returns in 2012-13, NIBL has highest returns in 2012-13, SCBN has highest returns in 2012-13, HBL has highest returns in 2012-13. The ROA figures shows that the performance of banks in generating returns on their assets is not satisfactory, whereas, HBL has seemed the second worst performer in regard of ROA. Out of the six commercial banks NBL has a more fluctuating ROA. The analysis of ROE figures from 2003-04 to 2012-13, the ROE ranged from $-56.64 \%$ to $162.5 \%$ over the study period. According the ROE, the performance of NABIL is better than other commercial banks, whereas, the worst performer in terms of ROE is RBB. Out of the six commercial banks NBL has a more fluctuating ROE. Similarly, other banks have a moderate fluctuation in its ROE. NBL and RBB are the worst performer within the study period.

Thus, it can be concluded that the Overall Banking Customers' Satisfaction is dependent to the five dimensions of service quality. These five dimensions have the greater predictability towards the customers' satisfaction in Nepalese commercial banks. No doubt, with the improvement of conditions of the five variables would definitely improve the quality of service in Nepalese commercial banks thus contributes to Overall Banking Customers' Satisfaction. It also can 
be concluded that higher the level of customer satisfaction leads to higher level of financial performance (i.e. ROA and ROE).

Thus, this study will not only be fruitful for performance of commercial banks but also important to those interested person, scholars, teachers, civil society, other stakeholders, businessmen and government for academically as well as policy perspectives.

\section{Implications for Future Research}

With this research on the relationship between service quality, and customers' satisfaction, this area is ripen for future research. There are several significant issues to be considered for future research. In order to improve the future study, the sample size could be collected from the manufacturing firms across the country (Nepal). This can further be compared to the service industries including the banking sector. The researcher also believes that extensive study with larger and more representative sample is important to give more generalized picture of the work activities performed by service quality and customer satisfaction in Nepalese context. Therefore, the new findings of manufacturing sector can give a new direction in understanding the subject phenomenon. Further research might be carried out with more sample of banks, as this study only based on six commercial banks of Nepal. It may give new understanding of the subject phenomenon. It can either attenuate or inflate correlations among variables. Likewise, the dimension of performance indicators may also increase e.g., ROA and ROE. It is only utilized to understand the influence of financial performance. Furthermore, other moderating variables like MIS, customer loyalty, firm's size, age and structure, manufacturing costs, customer retention, and the success of marketing strategy etc. can also be explored further to understand . In addition, a step further, Structural Equation Modeling approach of data analysis may be taken into account to moderating or mediating factors.

Last but not the least, the next few years are likely to see increased global competitiveness in the Nepalese business environment, and the banking sector will also mature in terms of operational years. Therefore, it would be interesting to expand the survey to provide longitudinal study of service quality and customers satisfaction which significantly influence the performance of the banks.

\section{References}

Agrawal G.(2014). Marketing Management,Kathmandu: MK Publications.

Akroush, M.N. (2008). Exploring the mediating effect of service quality implementation on the relationship between service quality and performance in the banking industry in Jordan. Global Business and Economics Review, 10(1): 98-122.

Berry, L. L., Seiders, K. and Grewal, D. (2002). Understanding service convenience. The Journal of Marketing, 66: 1-17.

Koirala K.D.( 2014) Fundamental of Marketing,Kathmandu: MK Publication Limited.

Chakravarty, S., Widdows, R. and Feinberg, R. (1996). How moments of truth define bankcustomer relationships. Journal of Retail Banking Services, 18(1): 29-34. 
Chang, J. C. (2008) Taiwanese Tourists perceptions of service quality on outbound guided package tours: A qualitative examination of the SERVQUAL dimensions. Journal of Vacation Marketing, 15(2): 164-178.

Cronin, J. J., Brady, M. K. and Hult, G. T. (2000) Assessing the effects of quality, value, and customer satisfaction on consumer behavioral intentions in service environments. Journal of Retailing, 76(2): 193-218.

Duff, A., Guo, X. and Hair, M. (2008). Service quality measurement in the Chinese corporate banking market. International Journal of Bank Marketing, 26(5): 305 - 327.

Duncan, E. and Elliott, G. (2004). Efficiency, customer service and financial performance among Australian financial institutions. The International Journal of Bank Marketing, 22(5): 319-342.

Eshghi, A., Haughton, D. and Topi, H. (2007). Determinants of customer loyalty in the wireless telecommunications industry. Telecommunications Policy, 31: 93-106.

Gerrard, P., Cunningham, J.B. \& Devlin, J.F. (2006). Why consumers are not using internet banking: a squalitative study. Journal of Service Marketing, 20(3): 160-168.

Gronroos, C. (2007) A service quality model and its marketing implications. European Journal of Marketing, 18: 35-44.

Gyawali A. (2011). Human Resource Management,Nepal:Reliance Publication House PVT LTD.

Guo, X., Duff, A. and Hair, M. (2008). Service quality measurement in the Chinese corporate banking market. International Journal of Bank Marketing, 26 (5): 305-27.

Ha, J., \& Jang, S. (2009). Perceived justice in service recovery and behavioral intentions: The role of relationship quality. International Journal of Hospitality Management, 28: 319-327.

Kang, G., and James, J. (2004). Service quality dimensions: an examination of Gronroos service quality model. Managing Service Quality, 14(4): 266-77.

Karatepe, O., Yavas, U. and Babakus, E. (2005). Measuring service quality of banks: Scale development and validation. Journal of Retailing and Consumer Services, 12: 373-383.

Kheng, L., Mahamad, O., and Ramayah, T. (2010). The impact of service quality on customer Loyalty: A study of banks in Penang, Malaysia. International Journal of Marketing Studies, 2(2): 57-66.

Kotler, P., and Armstrong, G. (2010). Principles of Marketing (13th ed.). Pearson Education, London.

Ladhari, R. (2008). Alternative measure of service quality: A review. Journal of Managing Service Quality, 18(1): 65-86.

Lewis, B. R., and Mitchell, V. W. (1990). Defining and measuring the quality of customer service. Marketing Intelligence \& Planning, 8(6): 11-17.

Magesh, R. (2012). A study on quality of service as a tool for enhancement of customer satisfaction in banks. Global Journal of Finance and Management, 2: 123-133. 
Meuter, M. L., Ostrom, A. L., Roundtree, R. I. and Bitner, M. J. (2000). Self-service technologies: Understanding customer satisfaction with technology-based service encounters. $A$ Marketing Assoc, 64: 50-64.

Naeem, H., and Saif, I. (2009) Service quality and its impact on customer satisfaction: An empirical evidence from the Pakistani banking sector. The International Business and Economics Research Journal. 8(12): 85-99.

Negi, R. (2009). Determining customer satisfaction through perceived service quality: A study of Ethiopian mobile users. International Journal of Mobile Marketing, 4(1): 31-38.

Newman, K. (2001). Interrogating SERVQUAL: a critical assessment of service quality measurement in a high street retail bank. International Journal of Bank Marketing, 19 (3): 126-39.

Nunnally, J. (1978). Psychometric Theory (2nd ed.). McGraw-Hill, New York.

Oliver, R. L. (1993). A conceptual model of service quality and service satisfaction: compatible goals, different concepts. Advances in Services Marketing and Management, 2: 65-85.

Parasuraman, A., Zeithaml, V. A. and Berry, L. L. (1985). A conceptual model of service quality and its implications for future research, Journal of Marketing, 49: 41-50.

Perng, Y. H. (2007). A service quality improvement dynamic decision support system for refurbishment contractors. Total Quality Management \& Business Excellence, 18(7): 731-749.

Pizam, A. and Ellis, T. (1999). Customer satisfaction and its measurement in hospitality enterprises. International Journal of Contemporary Hospitality Management, 11(7): 326-39.

Rubin S. (2010). Customers' satisfaction and service quality. Journal of Services Marketing, 14 (105) NA.

Solomon, R.C. (1998). The moral psychology of business: Care and compassion in the corporation. Business Ethics Quarterly, 8: 515-533.

Suresh Chandar, G. (2002). Determinants of customer perceived service quality: a confirmatory factor analysis approach. Journal of Services Marketing, 16(1): 9-34.

Tsoukatos, E. and Rand, G. (2006). Path analysis of perceived service quality, satisfaction and loyalty in greek insurance. Managing Service Quality, 16: 501-19.

Wilson, A., Zeithaml, V., Binter, M. and Gremler, D. (2008). Service Marketing: Integrating Customer Focus Across the Firm, McGraw-Hill, London.

Zeithaml, V. A. (2012). Service quality, profitability, and the economic worth of customers: What we know and what we need to learn. Journal of Academy of Marketing Science, 28(1): 67-85.

Zeithaml, V. A., Parasuraman, A. and Berry, L. L. (1990). Delivering Quality Service. The Free Press, New York. 